\title{
Personnel radiation dose assessment using a novel dosimeter in the department of radiology and dentistry in a medical facility in Delta State, South-South Nigeria: our experience in the last 4 years
}

\author{
Akintayo Daniel Omojola ${ }^{1}$, Michael Onoriode Akpochafor ${ }^{2}$, Samuel Olaolu Adeneye ${ }^{2}$, Ukeme Pius Aniekop ${ }^{1}$, \\ Margaret Idongesit Anizor ${ }^{1}$, Mary-Ann Etim Ekpo ${ }^{3}$, Chibuzo Bede Madu ${ }^{4}$ \\ ${ }^{1}$ Department of Radiology, Federal Medical Centre Asaba, Delta State, Nigeria \\ ${ }^{2}$ Department of of Radiation Biology, Radiotherapy, Radiodiagnosis and Radiography, College of Medicine, Lagos University Teaching \\ Hospital, Idi-Araba, Lagos, Nigeria \\ ${ }^{3}$ Department of Physics, Faculty of Science, University of Ibadan, Ibadan, Oyo State, Nigeria \\ ${ }^{4}$ Department of Radiology, Medical Physics Unit, University College Hospital, Ibadan, Oyo State, Nigeria
}

\begin{abstract}
Objectives. Large percentages of X-ray facilities in Nigeria do not use radiation monitoring device; a few percentage that use them do not evaluate or carryout out assessment programs to ascertain the detriment to occupationally exposed workers. This study was aimed at evaluating dose reports from 2013 to 2016 for personnel who operate radiation facilities and those that work within radiation field during certain X-ray procedures/examinations in the department of radiology and dentistry respectively; to ascertain if there is correlation between personnel dose and workload in both department and to determine if dose records are within acceptable limit recommended by the International Atomic Energy Agency (IAEA) safety series. Methods. Direct Ion Storage (DIS) dosimeter was used for a total of 35 occupationally exposed personnel who work in the department of radiology and dentistry. The DIS dosimeter was read every two months and results were authomatically saved on the instadose ${ }^{\mathrm{TM}}$ platform. Results. The mean (total) dose in radiology department for the first, second, third and fourth year was $0.17 \pm 0.08(3.52) \mathrm{mSv}, 0.08 \pm 0.03(0.77) \mathrm{mSv}, 0.07 \pm 0.04$ $(0.72) \mathrm{mSv}$ and $0.07 \pm 0.05(0.55) \mathrm{mSv}$ and in Dentistry was $0.08 \pm 0.02(0.73) \mathrm{mSv}, 0.05 \pm 0.02(0.42) \mathrm{mSv}$, $0.05 \pm 0.02(0.24) \mathrm{mSv}$ and $0.07 \pm 0.04(0.34) \mathrm{mSv}$; respectively. There was significant difference in mean personnel dose from 2013-2016 in Radiology $(p=0.028)$ and in Dentistry Department $(p=0.004)$. Correlation of workload and personnel dose in Radiology $(p=0.240)$ and Dentistry Department $(p=0.765)$ wasn't significant. There was no correlation in mean dose between both department $(p=0.256)$. Conclusion. Overall mean dose in both department for occupationally exposed personnel were below IAEA annual dose limit of $20 \mathrm{mSv}$ averaged over a period of 5 consecutive years. Dose reports of personnel in both department reduced as the year progressed due to radiation safety awareness.
\end{abstract}

Eur Res J 2018;4(2):70-78

Keywords: Direct ion storage dosimeter, ion-chamber, panoramic, cephalometric, workload 


\section{Introduction}

In late 1895, X-ray was discovered by Wilhelm Conrad Röntgen; a professor of Physics at the University of Würzburg Germany, ever since this discovery, Medicine and other fields have benefited immensely on its use [1-3]. The use of radiation for medical diagnostic examinations has contributed approximately over $95 \%$ of man-made radiation exposure and is only exceeded by natural background as a source of exposure to the world's population [4, 5]. The effect of exposure to ionising radiation became evident only a few years after its discovery. This scenario points to the fact that sites/environment where these machines are used may be under threat of secondary (scatter and leakage) radiation if no safety standards and precautions are followed [6-8]. This has made the International community to look into how this "useful but dangerous particle can be used effectively". In the same vein, several International bodies have been established with several roles on how well to manage ionizing radiations; one of such is the International Atomic Energy Agency (IAEA) [9]. Today, it is widely used in diagnosis and treatment of malignancy like cancer and other tumours. One major casualty of eventual fallout of radiation is the occupationally exposed personnel who spend their life time working within radiation facilities [10-12]. In Nigeria today there are over 4,000 X-ray machines in use [13]. The Nigerian Nuclear Regulatory Authority (NNRA) which is the country's national body is saddled with the responsibility of regulating radiological protection and nuclear safety so as to ensure the protection of life, health, property and the environment from the harmful effect of ionizing radiation [14].

In Nigeria, studies have shown that many hospitalbased Radiology/Dental department and privately owned diagnostic X-ray centres do not use radiation monitoring devices; a few that use them do not evaluate their reports/records over a long period of time $[15,16]$.

Several devices are currently in use for personnel dose measurement, such as the P-Channel MetalOxide Semiconductor (pMOS) with Radiation-Sensing Field Effect Transistor (RADFET) dosimeter $[17,18]$, Direct Ion Storage (DIS) dosimeters [19-23], Thermoluminescent dosimeter (TLD) [24] and Optically Stimulated Luminescent (OSL) dosimeters [25]. Currently in Nigeria only a few X-ray facility use OSL, majority use TLD [14].
More recently, the limitations of TLDs in Nigeria were attributed to problem arising from distances between dosimeter providers and end users, activation of heat while transporting them and the inability of end-users to get readouts at anytime they so desire. The above mentioned problems gave rise to the use of DIS dosimeter which can be read with a mobile device at anytime and anywhere.

This study would focus only on occupational exposed personnel who are assigned a new type of dosimeter called the DIS dosimeter. Also, the study will evaluate dose records of occupationally exposed personnel and those who occasionally work close to X-ray facilities both in Radiology and Dentistry Department and will determine if personnel radiation dose have direct correlation with workload which is a function of the X-ray output per week at a well defined point in each department and to determine if personnel mean effective doses are within acceptable dose limits, specified in the IAEA Safety Series and International Commission on Radiation Units and Measurements (ICRU) publication 60 and 103 [6, 7, 26, 27].

\section{Methods}

This research was a retrospective study, which was carried out from 2013 to 2016 . The personnel involved in this study were permanent staffs of the hospital. In Radiology Department they include: Radiologist, Radiographers, Imaging Technicians, Health Attendants/Nurses, Porters and a Medical Physicist. Exempted from this study were Intern Radiographers, undergraduate Clinical Radiography student, undergraduate Imaging Technicians, cleaners and clerical officers. In the same vein, personnel involved in this study from Dentistry Department were: Dental Surgeons and Dental Technicians. Exempted were undergraduate Dental Technicians. Intern and student were also monitored but their dose data/records were not included in this study. The reason for this exemption was because of their short stay in both departments. Ethical approval was granted by the institution where the research took place.

The material used for this study was Forty pieces of Direct Ion Storage Dosimeter (25 pieces of it was used in Radiology and 15 pieces was used in Dentistry department). The DIS dosimeter can be activated and assigned to a user. It can also be deactivated if a user no longer works with the X-ray facility and can be reassigned to another user. 


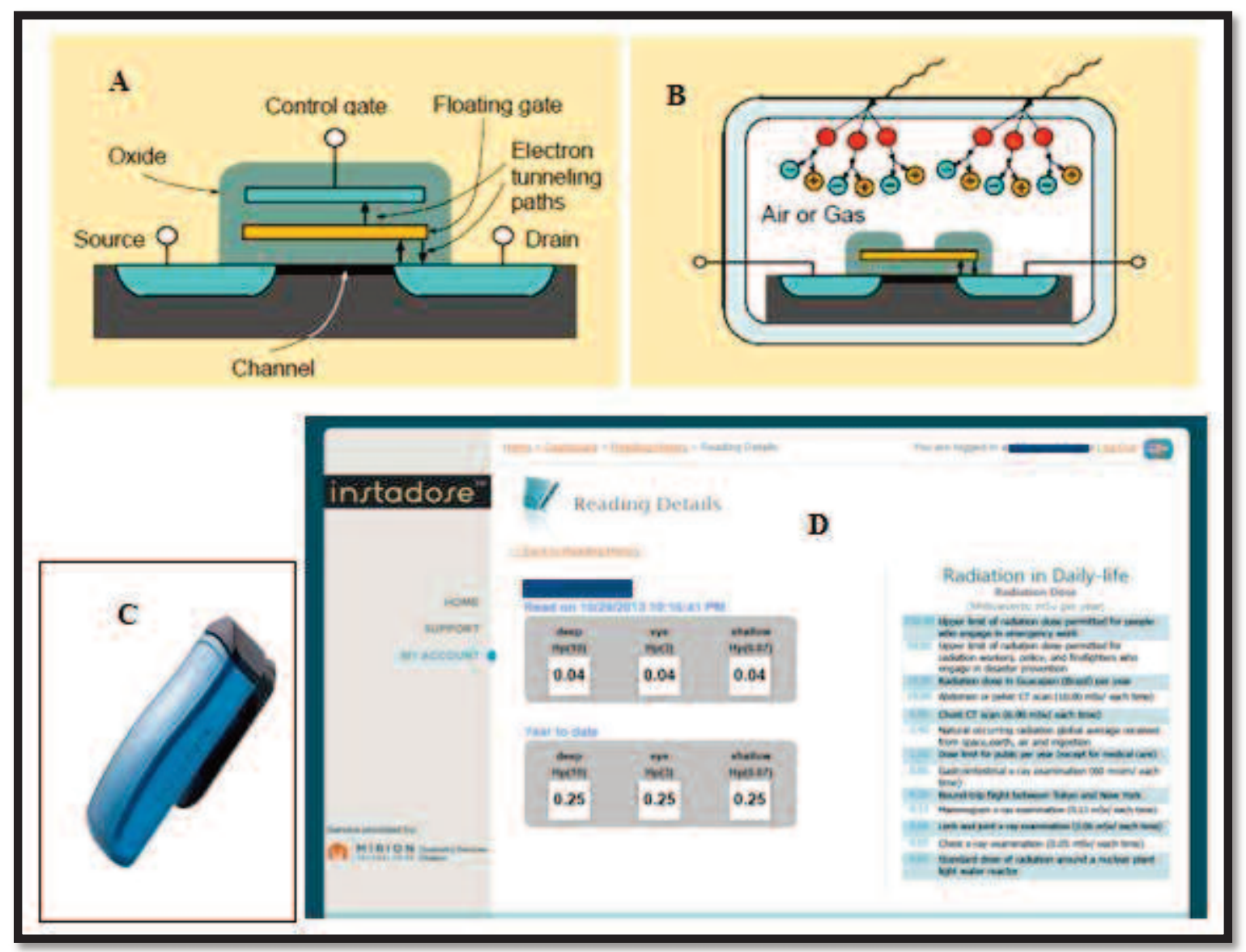

Figure 1. (A) Analog EEPROM memory cell, (B) DIS memory cell with the formation of a conductive wall (ion chamber), (C) DIS Dosimeter, (D) instadose ${ }^{\mathrm{TM}}$ Readout platform

The Radiological equipment used were two Conventional (both floor mounted) X-ray machine with maximum voltage/current of $125 \mathrm{kVp} / 500 \mathrm{mAs}$ and $150 \mathrm{kVp} / 630 \mathrm{mAs}$ respectively, one Fluoroscopy $\mathrm{X}$-ray machine with maximum voltage/current of $150 \mathrm{kVp} / 800 \mathrm{mAs}$ and one Mammography X-ray machine with maximum voltage/current of $35 \mathrm{kVp} / 500 \mathrm{mAs}$. The dental equipment used were five wall mounted intra-oral (IO) X-ray machine each of anode voltage and current of $70 \mathrm{kVp}$ and $7 \mathrm{~mA}$, one Panoramic/Cephalometric X-ray machine with maximum anode voltage and current of $90 \mathrm{kVp}$ and $10 \mathrm{~mA}$ and exposure timer of $13 \mathrm{sec}$ for Panoramic and $15 \mathrm{sec}$ for Cephalometric . The mentioned equipment was used throughout the study.

The principle of operation of the Direct Ion Storage (DIS) dosimeter is a combination of a hybrid of ion chamber and Floating Gate Metal-OxideSemiconductor Field-Effect Transistors (FGMOSFETs). In the DIS memory cell, the oxide layer surrounding the floating gate has an opening allowing the surface of the floating gate to be in direct contact with the surrounding air (or any other gas). The ionising radiation incident in the air or gas produces electron-ion pairs which is effectively formed between the wall and the floating gate by surrounding the entire structure with a conductive wall (ion chamber) with extremely high mobility and in case there is an electric field surrounding the floating gate, these charge carriers will be transferred efficiently to the gate before any recombination occurs [Figure 1A]. The DIS dosimeter contains an AnalogElectrical Erasable and Programmable Read Only Memory (EEPROM) cell [Figure 1B]. The charge in the floating gate can be set to a predetermined level by tunnelling electrons through the oxide layer. The charge is then stored permanently in the gate due to the fact that in the normal operating temperature range the electrons have a very low probability of exceeding the energy barriers in the metal-oxide and oxidesilicon interfaces carriers, of which Na-ions are usually the most dominant. Today it is possible to manufacture memory cells that are capable of retaining a stored charge for hundreds of years. Reading the stored information is carried out by measuring the channel conductivity of the transistor without disturbing the stored charge.

The DIS dosimeter has the capacity to measure 
Table 1. Radiology mean personnel dose for year 2013 \& 2014

\begin{tabular}{|c|c|c|c|c|c|c|}
\hline $\begin{array}{c}\text { Assigned } \\
\text { user }\end{array}$ & Group & $\begin{array}{c}\text { X-ray } \\
\text { Equipment used }\end{array}$ & $\begin{array}{c}\mathrm{H}_{\mathrm{P}}(10) \\
\text { Deep } \\
\text { dose (mSv) }\end{array}$ & $\begin{array}{c}\mathrm{H}_{\mathrm{P}}(0.07) \\
\text { Shallow } \\
\text { dose (mSv) }\end{array}$ & $\begin{array}{c}\mathrm{H}_{\mathrm{P}}(3) \\
\text { Eye } \\
\text { dose }(\mathrm{mSv}) \\
\end{array}$ & $\begin{array}{c}\text { Body } \\
\text { Region }\end{array}$ \\
\hline \multicolumn{7}{|l|}{ Year 2013} \\
\hline $\mathrm{R}_{1}$ & Radiographer & $\mathrm{C}$ & 0.10 & 0.10 & 0.10 & Torso \\
\hline $\mathrm{R}_{2}$ & Radiographer & $\mathrm{C} / \mathrm{M}$ & 0.10 & 0.10 & 0.10 & Torso \\
\hline $\mathrm{R}_{3}$ & Radiographer & $\mathrm{C} / \mathrm{M} / \mathrm{F}$ & 0.17 & 0.17 & 0.17 & Torso \\
\hline $\mathrm{R}_{4}$ & Radiographer & $\mathrm{C} / \mathrm{M} / \mathrm{F}$ & 0.13 & 0.13 & 0.13 & Torso \\
\hline $\mathrm{R}_{5}$ & Radiographer & $\mathrm{C} / \mathrm{M} / \mathrm{F}$ & 0.20 & 0.20 & 0.20 & Torso \\
\hline $\mathrm{R}_{6}$ & Radiographer & $\mathrm{C} / \mathrm{F}$ & 0.17 & 0.17 & 0.17 & Torso \\
\hline $\mathrm{R}_{7}$ & Radiographer & $\mathrm{C} / \mathrm{F}$ & 0.18 & 0.18 & 0.18 & Torso \\
\hline $\mathrm{R}_{8}$ & Radiographer & $\mathrm{C} / \mathrm{F}$ & 0.12 & 0.12 & 0.12 & Torso \\
\hline $\mathrm{R}_{9}$ & Radiographer & $\mathrm{C} / \mathrm{F}$ & 0.15 & 0.15 & 0.15 & Torso \\
\hline $\mathrm{R}_{10}$ & Radiographer & $\mathrm{C} / \mathrm{F}$ & 0.11 & 0.11 & 0.11 & Torso \\
\hline $\mathrm{R}_{11}$ & Radiographer & $\mathrm{C} / \mathrm{F}$ & 0.15 & 0.15 & 0.15 & Torso \\
\hline $\mathrm{R}_{12}$ & Porter & $* * *$ & 0.09 & 0.09 & 0.09 & Torso \\
\hline $\mathrm{R}_{13}$ & Health. A/Nurse & $\mathrm{C} / \mathrm{M} / \mathrm{F}$ & 0.07 & 0.07 & 0.07 & Torso \\
\hline $\mathrm{R}_{14}$ & Technicians & $* * *$ & 0.05 & 0.05 & 0.05 & Torso \\
\hline $\mathrm{R}_{15}$ & Technicians & $* * *$ & 0.10 & 0.10 & 0.10 & Torso \\
\hline $\mathrm{R}_{16}$ & Technicians & $* * *$ & 0.08 & 0.08 & 0.08 & Torso \\
\hline $\mathrm{R}_{17}$ & Technicians & $* * *$ & 0.09 & 0.09 & 0.09 & Torso \\
\hline $\mathrm{R}_{18}$ & Technicians & $* * *$ & 0.07 & 0.07 & 0.07 & Torso \\
\hline $\mathrm{R}_{19}$ & Radiologist & $\mathrm{C} / \mathrm{F}$ & 0.44 & 0.44 & 0.44 & Torso \\
\hline $\mathrm{R}_{20}$ & Radiologist & $\mathrm{C} / \mathrm{F}$ & 0.45 & 0.45 & 0.45 & Torso \\
\hline $\mathrm{R}_{21}$ & Radiologist & $\mathrm{C} / \mathrm{F}$ & 0.50 & 0.50 & 0.50 & Torso \\
\hline \multicolumn{7}{|l|}{ Year 2014} \\
\hline $\mathrm{R}_{1}$ & Radiographer & $\mathrm{C}$ & 0.07 & 0.07 & 0.07 & Torso \\
\hline $\mathrm{R}_{2}$ & Radiographer & $\mathrm{C} / \mathrm{M} / \mathrm{F}$ & 0.04 & 0.04 & 0.04 & Torso \\
\hline $\mathrm{R}_{3}$ & Radiographer & $\mathrm{C} / \mathrm{F}$ & 0.09 & 0.09 & 0.09 & Torso \\
\hline $\mathrm{R}_{4}$ & Radiographer & $\mathrm{C} / \mathrm{M} / \mathrm{F}$ & 0.10 & 0.10 & 0.10 & Torso \\
\hline $\mathrm{R}_{5}$ & Radiographer & $\mathrm{C} / \mathrm{M} / \mathrm{F}$ & 0.09 & 0.09 & 0.09 & Torso \\
\hline $\mathrm{R}_{6}$ & Radiographer & $\mathrm{C} / \mathrm{F}$ & 0.05 & 0.05 & 0.05 & Torso \\
\hline $\mathrm{R}_{7}$ & Porter & $* * *$ & 0.04 & 0.04 & 0.04 & Torso \\
\hline $\mathrm{R}_{8}$ & Technicians & $* * *$ & 0.06 & 0.06 & 0.06 & Torso \\
\hline $\mathrm{R}_{9}$ & Radiologist & $\mathrm{C} / \mathrm{F}$ & 0.12 & 0.12 & 0.12 & Torso \\
\hline $\mathrm{R}_{10}$ & Radiologist & $\mathrm{C} / \mathrm{F}$ & 0.11 & 0.11 & 0.11 & Torso \\
\hline
\end{tabular}

deep, shallow and lens dose. Measurements at the deep dose equivalent [HP (10)] are a concept that applies to external whole body radiation. It is the dose equivalent at a tissue depth of 1 centimetre. This quantity is usually determined using a "whole body" dosimeter. It does not apply to weakly penetrating radiation such as alpha particles or low-energy electrons. Also, the shallow dose equivalent [HP (0.07)] applies to external exposure of the skin of the whole body or the skin of an extremity. It is the dose equivalent just below the cornified layer of the skin at a tissue depth of 0.007 centimetre averaged over an area of 10 square centimetres. Thirdly, the lens or eye dose equivalent [HP (3)] applies to external exposure to the lens of the eye. It is the dose equivalent at a tissue depth of 0.3 centimetres. This quantity is usually determined using a "whole body" dosimeter worn at or near the torso level. It does not apply to weakly penetrating radiation such as alpha particles or lowenergy electrons. The DIS minimum reportable dose is $3 \mathrm{rem}[0.03$ millisievert $(\mathrm{mSv})]$ and $1 \mathrm{rem}(0.01$ $\mathrm{mSv}$ ) upon reset, with low limit of detection of 1 rem $(0.01 \mathrm{mSv})$. The useful dose range is $0.01 \mathrm{mSv}-5 \mathrm{~Sv}$, with energy response of $5 \mathrm{keV}-6 \mathrm{MeV}$ [Figure $1 C \& 1 \mathrm{D}]$. The algorithm of the instadose ${ }^{\mathrm{TM}}$ platform will only compute dose whenever equivalent dose is $0.03 \mathrm{mSv}$ and will record "below reportable dose (BRD)" which is clearly shown on the readout of the instadose $^{\mathrm{TM}}$ platform whenever dose is $<0.03 \mathrm{mSv}$. The X-ray machine used by radiographer $(\mathrm{C} / \mathrm{F} / \mathrm{M})$ and 
Table 2. Radiology mean personnel dose for year 2015 \& 2016

\begin{tabular}{|c|c|c|c|c|c|c|}
\hline $\begin{array}{c}\text { Assigned } \\
\text { user }\end{array}$ & Group & $\begin{array}{c}\text { X-ray } \\
\text { Equipment used }\end{array}$ & $\begin{array}{c}\mathrm{H}_{\mathrm{P}}(10) \\
\text { Deep } \\
\text { dose }(\mathrm{mSv})\end{array}$ & $\begin{array}{c}\mathrm{H}_{\mathrm{P}}(0.07) \\
\text { Shallow } \\
\text { dose }(\mathrm{mSv})\end{array}$ & $\begin{array}{c}\mathrm{H}_{\mathrm{P}}(3) \\
\text { Eye } \\
\text { dose } \\
(\mathrm{mSv})\end{array}$ & $\begin{array}{l}\text { Body } \\
\text { region }\end{array}$ \\
\hline \multicolumn{7}{|l|}{ Year 2015} \\
\hline $\mathrm{R}_{1}$ & Radiographer & $\mathrm{C} / \mathrm{M} / \mathrm{F}$ & 0.04 & 0.04 & 0.04 & Torso \\
\hline $\mathrm{R}_{2}$ & Radiographer & $\mathrm{C} / \mathrm{F}$ & 0.04 & 0.04 & 0.04 & Torso \\
\hline $\mathrm{R}_{3}$ & Radiographer & $\mathrm{C} / \mathrm{M} / \mathrm{F}$ & 0.03 & 0.03 & 0.03 & Torso \\
\hline $\mathrm{R}_{4}$ & Radiographer & $\mathrm{C} / \mathrm{M} / \mathrm{F}$ & 0.08 & 0.08 & 0.08 & Torso \\
\hline $\mathrm{R}_{5}$ & Radiographer & $\mathrm{C} / \mathrm{F}$ & 0.10 & 0.10 & 0.10 & Torso \\
\hline $\mathrm{R}_{6}$ & Radiographer & $\mathrm{C} / \mathrm{F}$ & 0.03 & 0.03 & 0.03 & Torso \\
\hline $\mathrm{R}_{7}$ & Health. A/Nurse & $\mathrm{C} / \mathrm{M} / \mathrm{F}$ & 0.04 & 0.04 & 0.04 & Torso \\
\hline $\mathrm{R}_{8}$ & Technicians & $* * *$ & 0.03 & 0.03 & 0.03 & Torso \\
\hline $\mathrm{R}_{9}$ & Technicians & $* * *$ & 0.09 & 0.09 & 0.09 & Torso \\
\hline $\mathrm{R}_{10}$ & Radiologist & $\mathrm{C} / \mathrm{F}$ & 0.10 & 0.10 & 0.10 & Torso \\
\hline $\mathrm{R}_{11}$ & Radiologist & $\mathrm{C} / \mathrm{F}$ & 0.14 & 0.14 & 0.14 & Torso \\
\hline \multicolumn{7}{|l|}{ Year 2016} \\
\hline $\mathrm{R}_{1}$ & Radiographer & $\mathrm{C} / \mathrm{M} / \mathrm{F}$ & 0.06 & 0.06 & 0.06 & Torso \\
\hline $\mathrm{R}_{2}$ & Radiographer & $\mathrm{C} / \mathrm{M}$ & 0.03 & 0.03 & 0.03 & Torso \\
\hline $\mathrm{R}_{3}$ & Radiographer & $\mathrm{C} / \mathrm{F}$ & 0.15 & 0.15 & 0.15 & Torso \\
\hline $\mathrm{R}_{4}$ & Radiographer & $\mathrm{C} / \mathrm{M} / \mathrm{F}$ & 0.03 & 0.03 & 0.03 & Torso \\
\hline $\mathrm{R}_{5}$ & Radiographer & $\mathrm{C} / \mathrm{M} / \mathrm{F}$ & 0.04 & 0.04 & 0.04 & Torso \\
\hline $\mathrm{R}_{6}$ & Technicians & $* * *$ & 0.04 & 0.04 & 0.04 & Torso \\
\hline $\mathrm{R}_{7}$ & Radiologist & $\mathrm{C} / \mathrm{F}$ & 0.12 & 0.12 & 0.12 & Torso \\
\hline $\mathrm{R}_{8}$ & Radiologist & $\mathrm{C} / \mathrm{F}$ & 0.08 & 0.08 & 0.08 & Torso \\
\hline
\end{tabular}

*** Personnel proximal to the facility, $\mathrm{C} / \mathrm{M} / \mathrm{F}=$ Conventional/ Mammographic/ Fluoroscopic, $\mathrm{A}=$ Attendant

technicians $(\mathrm{C} / \mathrm{P} / \mathrm{IO})$ were indicated in the tables and personnel categorized as those that work proximal to facility operators (radiographer and dental technicians) were left empty [Table 1, 2 and 3].

\section{Statistical Analysis}

Data analysis was done using Microsoft Excel and SPSS Version 16.0 Software. A p value $<0.05$ was considered to be statistically significant.

\section{Results}

The mean/total dose in Radiology Department in 2013 was $0.17 \pm 0.08$ (3.52) $\mathrm{mSv}, 2014$ was $0.08 \pm 0.03$ (0.77) $\mathrm{mSv}, 2015$ was $0.07 \pm 0.04(0.72) \mathrm{mSv}$ and 2016 was $0.07 \pm 0.05(0.55) \mathrm{mSv}$. The highest readout was noticed from the Radiologist unit $(0.5 \mathrm{mSv})$ [Tables 1 and 2]. One-Sample T Test in Radiology department show that in 2013 the mean dose report among personnel had statistically significant difference $(p=0.000)$, this was also similar in $2014(p=0.000)$ [Table 1], $2015(p=0.000)$ and $2016(p=0.003)$ [Table $2]$; respectively. Personnel mean dose from the first year of study (2013) to the fourth year of study (2016) showed that there was significant difference in dose value $(p=0.028)$.

The mean/total dose in Dentistry Department in 2013 was $0.08 \pm 0.02(0.73) \mathrm{mSv}$ with the highest readout from the Dental Technician, 2014 was $0.05 \pm$ $0.02(0.42) \mathrm{mSv}$ with the highest readout from the Dental Surgeon, 2015 was $0.05 \pm 0.02(0.24) \mathrm{mSv}$ with the highest readout from the Dental Technician and 2016 was $0.07 \pm 0.04(0.34) \mathrm{mSv}$ with the highest readout from the Dental Surgeon (Table 3). In the same vein, One-Sample T Test in Dentistry department show that in 2013 the mean dose among personnel had statistically significant difference $(p=0.000)$, this was also similar in $2014(p=0.002), 2015(p=0.003)$ and $2016(p=0.012$ ) (Table 3); respectively. Similarly, personnel mean dose from the first year of study (2013) to the fourth year of study (2016) showed that there was generally significant difference in dose value $(p=0.004)$

The average number of patient per week/workload in Radiology Department in 2103 was $187 / 340 \mathrm{~mA}-$ $\mathrm{min} / \mathrm{Wk}, 2014$ was 159/290mA-min/Wk, 2015 was $185 / 328 \mathrm{~mA}-\mathrm{min} / \mathrm{Wk}$ and 2016 was $160 / 242 \mathrm{~mA}-$ 
Table 3. Mean dose from 2013-2016 in the dental department using Panoramic, Cephalometric and Intra-Oral X-ray machine

\begin{tabular}{|c|c|c|c|c|c|c|}
\hline $\begin{array}{c}\text { Assigned } \\
\text { user } \\
\end{array}$ & Group & $\begin{array}{c}\text { X-ray } \\
\text { Equipment used }\end{array}$ & $\begin{array}{c}\mathrm{H}_{\mathrm{P}}(10) \\
\text { Deep } \\
\text { dose }(\mathrm{mSv}) \\
\end{array}$ & $\begin{array}{c}\mathrm{H}_{\mathrm{P}}(0.07) \\
\text { Shallow } \\
\text { dose }(\mathrm{mSv}) \\
\end{array}$ & $\begin{array}{c}\mathrm{H}_{\mathrm{P}}(3) \\
\text { Eye } \\
\text { dose }(\mathrm{mSv}) \\
\end{array}$ & $\begin{array}{l}\text { Body } \\
\text { region }\end{array}$ \\
\hline \multicolumn{7}{|l|}{ Year 2013} \\
\hline $\mathrm{R} 1$ & Dental technician & $\mathrm{C} / \mathrm{P} / \mathrm{IO}$ & 0.05 & 0.05 & 0.05 & Torso \\
\hline $\mathrm{R} 2$ & Dental technician & $\mathrm{C} / \mathrm{P} / \mathrm{IO}$ & 0.08 & 0.08 & 0.08 & Torso \\
\hline R3 & Dental technician & $\mathrm{C} / \mathrm{P} / \mathrm{IO}$ & 0.05 & 0.05 & 0.05 & Torso \\
\hline $\mathrm{R} 4$ & Dental technician & $\mathrm{C} / \mathrm{P} / \mathrm{IO}$ & 0.12 & 0.12 & 0.12 & Torso \\
\hline R5 & Dental technician & $\mathrm{C} / \mathrm{P} / \mathrm{IO}$ & 0.08 & 0.08 & 0.08 & Torso \\
\hline R6 & Dental technician & $\mathrm{C} / \mathrm{P} / \mathrm{IO}$ & 0.08 & 0.08 & 0.08 & Torso \\
\hline R7 & Dental technician & $\mathrm{C} / \mathrm{P} / \mathrm{IO}$ & 0.07 & 0.07 & 0.07 & Torso \\
\hline R8 & Dental Surgeon & $* * *$ & 0.10 & 0.10 & 0.10 & Torso \\
\hline R9 & Dental Surgeon & $* * *$ & 0.10 & 0.10 & 0.10 & Torso \\
\hline \multicolumn{7}{|l|}{ Year 2014} \\
\hline $\mathrm{R} 1$ & Dental technician & $\mathrm{C} / \mathrm{P} / \mathrm{IO}$ & 0.04 & 0.04 & 0.04 & Torso \\
\hline $\mathrm{R} 2$ & Dental technician & $\mathrm{C} / \mathrm{P} / \mathrm{IO}$ & 0.03 & 0.03 & 0.03 & Torso \\
\hline R3 & Dental technician & $\mathrm{C} / \mathrm{P} / \mathrm{IO}$ & 0.03 & 0.03 & 0.03 & Torso \\
\hline R4 & Dental technician & $\mathrm{C} / \mathrm{P} / \mathrm{IO}$ & 0.04 & 0.04 & 0.04 & Torso \\
\hline R5 & Dental technician & $\mathrm{C} / \mathrm{P} / \mathrm{IO}$ & 0.06 & 0.06 & 0.06 & Torso \\
\hline R6 & Dental technician & $\mathrm{C} / \mathrm{P} / \mathrm{IO}$ & 0.05 & 0.05 & 0.05 & Torso \\
\hline R7 & Dental Surgeon & $* * *$ & 0.10 & 0.10 & 0.10 & Torso \\
\hline $\mathrm{R} 8$ & Dental Surgeon & $* * *$ & 0.07 & 0.07 & 0.07 & Torso \\
\hline \multicolumn{7}{|l|}{ Year 2015} \\
\hline R1 & Dental technician & $\mathrm{C} / \mathrm{P} / \mathrm{IO}$ & 0.04 & 0.04 & 0.04 & Torso \\
\hline $\mathrm{R} 2$ & Dental technician & $\mathrm{C} / \mathrm{P} / \mathrm{IO}$ & 0.07 & 0.07 & 0.07 & Torso \\
\hline R3 & Dental technician & $\mathrm{C} / \mathrm{P} / \mathrm{IO}$ & 0.06 & 0.06 & 0.06 & Torso \\
\hline R4 & Dental technician & $\mathrm{C} / \mathrm{P} / \mathrm{IO}$ & 0.03 & 0.03 & 0.03 & Torso \\
\hline $\mathrm{R} 5$ & Dental Surgeon & $* * *$ & 0.04 & 0.04 & 0.04 & Torso \\
\hline \multicolumn{7}{|l|}{ Year 2016} \\
\hline $\mathrm{R} 1$ & Dental technician & $\mathrm{C} / \mathrm{P} / \mathrm{IO}$ & 0.04 & 0.04 & 0.04 & Torso \\
\hline $\mathrm{R} 2$ & Dental technician & $\mathrm{C} / \mathrm{P} / \mathrm{IO}$ & 0.03 & 0.03 & 0.03 & Torso \\
\hline R3 & Dental technician & $\mathrm{C} / \mathrm{P} / \mathrm{IO}$ & 0.12 & 0.12 & 0.12 & Torso \\
\hline R4 & Dental Surgeon & $* * *$ & 0.05 & 0.05 & 0.05 & Torso \\
\hline R5 & Dental Surgeon & $* * *$ & 0.10 & 0.10 & 0.10 & Torso \\
\hline
\end{tabular}

$\mathrm{P}=$ Panoramic, $\mathrm{C}=$ Cephalometric, $\mathrm{IO}=$ Intra-Oral, $* * *$ Personnel proximal to the facility

$\mathrm{min} / \mathrm{Wk}$, with 2013 having the highest number of patient per week [Table 4].

The average number of patient per week in Dentistry Department in 2013 was 62/7.1mA$\mathrm{min} / \mathrm{Wk}, 2014$ was 83/9.3mA-min/Wk, 2015 was $65 / 7.3 \mathrm{~mA}-\mathrm{min} / \mathrm{Wk}$ and 2016 was $47 / 5.2 \mathrm{~mA}-$ $\mathrm{min} / \mathrm{Wk}$, with 2013 having the highest number of patient per week [Table 4].

\section{Discussion}

Total effective dose received by radiographers in Radiology Department in 2013 was the highest (1.58 $\mathrm{mSv}$ ) which represent $44.9 \%$ of the total dose received in that year; radiologist had a total dose of $1.39 \mathrm{mSv}$ which was $39.5 \%$ of the total dose; followed by technicians who had a total dose of $0.39 \mathrm{mSv}$ which was $11.1 \%$ of the total dose, while porters and health attendance /Nurse had $0.16 \mathrm{mSv}$ corresponding to $4.5 \%$ of the total dose. The highest recorded dose was from Radiologists who were engaged with special examination while using the fluoroscopy unit.

In 2014, radiographers dose reduced by $72.2 \%$ against 2013 dose value and radiologist dose reduced by $83.5 \%$ in 2014 against 2013 dose value. This reduction was attributed to dose values that were below reportable dose (BRD) from the instadose ${ }^{\mathrm{TM}}$ readout of some personnel which was necessitated by awareness and compliance with simple radiation safety rules during exposure. The highest dose in 2014 
Table 4. Average workload from 2013-2016 in Radiology and Dentistry Department

\begin{tabular}{ccc}
\hline Radiology Department & $\begin{array}{c}\text { Average number of patient } \\
\text { per week }\end{array}$ & $\begin{array}{c}\text { Workload (W) } \\
\text { (mA-min/Wk) }\end{array}$ \\
\hline 2013 & 187 & 340 \\
2014 & 159 & 290 \\
2015 & 185 & 328 \\
2016 & 160 & 242 \\
\hline & & \\
Dentistry Department & & Workload (W) \\
\hline Year & Average number of patient & 7.1 \\
& per week & 9.3 \\
2013 & 62 & 7.3 \\
2014 & 83 & 5.2 \\
2015 & 65 & (mA-min/Wk) \\
2016 & 47 &
\end{tabular}

was from the radiologist unit $(0.12 \mathrm{mSv})$ which was $76 \%$ lower than the highest dose value in 2013. Although, the highest dose value was far below 20 mSv IAEA limit in a year $[6,7,26,27]$.

Radiographers dose record further reduced by $79.7 \%$ in 2015 against 2013 record and radiologist dose slightly increased from $16.6 \%$ to $17.3 \%$ from 2014 to 2015 . The highest dose was still seen to be among the radiologist, while the least dose was from the health attendant/ nurse $(0.04 \mathrm{mSv})$. In 2016, radiographer dose record was $80.4 \%$ lower than 2013 record with that of the radiologist being $85.6 \%$ lower than 2013 dose record. The highest (radiologist) and least dose (technician) were $0.2 \mathrm{mSv}$ and $0.04 \mathrm{mSv}$, respectively. In general, radiologist effective doses were the highest. The next are radiographer who must times stay behind the lead screen or shield during radiographic, mammographic and fluoroscopic examinations. The dose received by the radiologist, radiographer and health attendance who work closely with the patient might largely be due to secondary radiation which are usually scatter radiation from patient or any other material in the X-ray room or leakage radiation from the tube head.

Annual mean effective dose in radiology department (using conventional, fluoroscopic and mammographic X-ray) varied in the range of 0.03 $0.50 \mathrm{mSv}$ over four years. This value was seen to be below a study conducted in 2010 using TLDs by Jabeen et al. [28] in Pakistan whose annual average effective dose in Diagnostic Radiology (DR) using conventional, fluoroscopic and mammographic X-ray machines from 2003-2007 ranged from 1.22-1.71mSv. Also this study's mean annual dose $(0.17 \mathrm{mSv})$ in radiology department was lower compared to Nassef and Kinsara's study [29] whose annual mean dose was $0.66 \mathrm{mSv}$ in diagnostic radiology using TLDs. Radiologist mean effective dose in this study was 0.23 $\mathrm{mSv}$ with range of $0.08-0.5 \mathrm{mSv}$; it was lower compared to Nassef and Kinsara's study [29] whose mean effective dose was $0.39 \mathrm{mSv}$ with a range of 0.09-1.49 mSv.

Evaluation of dose value in Radiology Department between 2013 and 2014 show that difference existed in personnel dose $(p=0.001)$, similar result was noticed between 2013 and 2015 in personnel dose $(p=0.002)$, continuous trend was noticed between 2013 and 2016 likewise in personnel dose $(p=0.002)$. There was no difference in personnel dose between 2014 and 2015 $(p=0.171)$, also no significant difference was noticed between 2014 and 2016 ( $p=0.643$ ) and between 2015 and 2016 in personnel dose $(p=0.970)$.

The average number of patient per week and workload from 2013-2016 in Radiology Department were: 187/340, 187/290, 187/328 and 187/242mA-min per week; respectively with no significant correlation between personnel dose and workload $(p=0.394)$ [Table 3]

Dental technicians in 2013 had a total dose of 0.53 $\mathrm{mSv}$ which accounted for $72.6 \%$ of the total dose received and the total dental surgeon dose was 0.2 $\mathrm{mSv}$ which translated to $27.4 \%$ of total dose received. Reduction of dose was noticed in 2014 for technicians (with total wearer of eight) which were $42.5 \%$ lower than those obtained in 2013 with total wearer of nine. It was noticed that two technicians dose value were below reportable dose throughout the year. Total dose in 2015 for technicians were $0.2 \mathrm{mSv}$ with a dose reduction of $20 \%$ from 2014 (where technicians total dose was $0.25 \mathrm{mSv}$ ). There was reduction in the 
number of technician and dental surgeon because their dose values were below reportable dose throughout the year. 2016 technician dose value was 5\% lower than 2015. There was gradual reduction in the number technicians (Table 3), this was due to the fact that some personnel dosimeters were below reportable dose. Generally dose values in the dental department were below $20 \mathrm{mSv}$ annual dose limit [6, 7, 26, 27].

A study conducted by Gray et al. [30] using TLD investigated the dose received by dental staff using Intra-oral X-ray unit. Measured mean monthly dose was $0.0078 \mathrm{mSv}$; this value was lower compared to our study which was $0.005 \mathrm{mSv} / \mathrm{month}$ with the DIS dosimeter.

Evaluation of dose value between 2013 and 2014 show that difference existed in personnel dose ( $p=0.021)$, deviation in result was noticed between 2013 and 2015 in personnel dose $(p=0.274)$, between 2013 and 2016 personnel dose was different $(\mathrm{p}=0.038)$. There was no difference in personnel dose between 2014 and 2015 ( $p=0.627$ ), also no significant difference was noticed between 2014 and 2016 $(p=1.000)$ and between 2015 and 2016 in personnel dose $(p=0.484)$.

The average number of patient per week and workload from 2013-2016 in Dentistry Department were: $62 / 7.1,83 / 9.3,65 / 7.3$ and 47/5.2mA-min per week respectively with no significant correlation between personnel dose and workload $(p=0.413)$ [Table 4].

\section{The Limitations of the Study}

Personnel not regularly wearing their DIS dosimeter was challenging in getting accurate dose record most especially among radiographers, radiologist and dental surgeons. Another limitation was "below reportable dose" which eventually count personnel dose as insignificant.

\section{Conclusions}

The first year of the DIS dosimeter had the highest dose in both departments but as the year progresses personnel dose gradually reduces due to radiation protection training that was implemented. Personnel dose report in radiology and dentistry department was generally below IAEA/ICRU annual dose limit of 20 $\mathrm{mSv}$ averaged over a period of 5 consecutive years.

\section{Authorship declaration}

All authors listed meet the authorship criteria according to the latest guidelines of the International Committee of Medical Journal Editors, and all authors are in agreement with the manuscript.

\section{Conflict of interest}

The authors disclosed no conflict of interest during the preparation or publication of this manuscript.

\section{Financing}

The authors disclosed that they did not receive any grant during conduction or writing of this study.

\section{Contributions}

ADO: involved in concept, design, literature search, data acquisition and analysis, statistical analysis and manuscript preparation, editing and reviewing, MOA: involved in design, literature search, data acquisition and analysis, statistical analysis and manuscript preparation, editing and reviewing, SOA: involved in literature search, data analysis, statistical analysis and manuscript preparation, UPA: involved in literature search, data analysis and statistical analysis, MIA: involved in data analysis and statistical analysis, MEE: involved in literature search and manuscript reviewing and CBM: involved in data acquisition and manuscript editing

\section{References}

[1] Frankel RI. Centennial of Röntgen's discovery of x-rays. West J Med 1996;164:497-501.

[2] Wyman SM. Department of Radiology, Massachusetts General Hospital: a brief history. AJR Am J Roentgenol 1993;160:1141-4.

[3] Spiegel PK. The first clinical X-ray made in America--100 years. AJR Am J Roentgenol 1995;164:241-3.

[4] Mazrani W, McHugh K, Marsden PJ. The radiation burden of radiological investigations. Arch Dis Child 2007;92:1127-31.

[5] Pearce MS, Salotti JA, McHugh K, Metcalf W, Kim KP, Craft AW, et al. CT scans in young people in Northern England: trends and patterns 1993-2002. Pediatr Radiol 2011;41:832-8.

[6] International Atomic Energy Agency (IAEA). Applying radiation safety standards in diagnostic radiology and interventional procedures using x rays. Safety Reports Series No. 39: Vienna IAEA Publication; 2006.

[7] International Atomic Energy Agency (IAEA). Radiation protection and safety of radiation sources: international basic safety standards. IEAE Safety Standards Series No. GSR Part 3 (Interim): Vienna IAEA Publication; 2011.

[8] International Electrotechnical Commission (IEC). Medical electrical equipment-part 2-43: particular requirements for the safety of x-ray equipment for interventional procedures. IEC Report 60601. Geneva: IEC Publication; 2000.

[9] International Atomic Energy Agency (IAEA). Responsibilities and capabilities of a nuclear energy programme implementing organization. IAEA Nuclear Energy Series No. NG-T-3.6: Vienna IAEA Publication; 2009. 
[10] Shrader-Frechette K. Trimming Exposure Data, Putting Radiation Workers at Risk: Improving Disclosure and Consent through a National Radiation Dose-Registry. Am J Public Health 2007;97:1782-6.

[11] Cardis E, Gilbert ES, Carpenter L, Howe G, Kato I, Armstrong BK, et al. Effects of low doses and low dose rates of external ionizing radiation: cancer mortality among nuclear industry workers in three countries. Radiat Res 1995;142:117-32.

[12] Wang JX, Inskip PD, Boice JD Jr, Li BX, Zhang JY, Fraumeni JF Jr. Cancer incidence among medical diagnostic X-ray workers in China, 1950 to 1985. Int J Cancer 1990;45:889-95.

[13] Akpochafor MO, Omojola AD, Soyebi KO, Adeneye SO, Aweda MA, Ajayi HB. Assessment of peak kilovoltage accuracy in ten selected $\mathrm{X}$-ray centers in Lagos metropolis, South-Western Nigeria: A quality control test to determine energy output accuracy of an X-ray generator. J Health Res Rev 2016;3:60-5.

[14] Eze CU, Abonyi LC, Njoku J, Irurhe NK, Olowu O. Assessment of radiation protection practices among radiographers in Lagos, Nigeria. Niger Med J 2013;54:386-91.

[15] Okaro AO, Ohagwu CC, Njoku J. Evaluation of personnel radiation monitoring in radiodiagnostic centres in South Eastern Nigeria. African J of Basic \& Appl Sci 2010;2:49-53.

[16] Eze KC, Nzotta CC, Marchie TT, Okegbunam B, Eze TE. The state of occupational radiation protection and monitoring in public and private X-ray facilities in Edo state, Nigeria. Niger J Clin Pract 2011;14:30810.

[17] Pejović S, Bosnjakovic P, Ciraj-Bjelac O, Pejović M. Characteristics of a pMOS suitable for use in radiotherapy. Appl Radiat Isot 2013;77:449.

[18] Gladstone DJ, Lu XQ, Humm JL, Bowman HF, Chin LM. A miniature MOSFET radiation dosimeter probe. Med Phys 1994;21:1721-
8

[19] Yasuda H. Responses of a direct ion storage dosimeter (DIS-1) to heavy charged particles. Radiat Res 2001;156:805-8.

[20] Kahilainen J. The direct ion storage dosimeter. Radiat Prot Dosim 1996;66:459-62.

[21] Wernli C. Dosimetric characteristics of a novel personal dosimeter based on direct ion storage (DIS). Radiat Prot Dosim 1996;66:23-8.

[22] Wernli C. Direct ion storage (DIS) Dosimeters for individual monitoring. Radiat Prot Dosim 1998;77:253-6.

[23] Kosunen A, Vartianinen E, Hyvönen H, Rantanen E, Kahilainen J. Testing of a TLD and a Direct Ion Storage (DIS) dosemeter for use as a personal dosemeter. Radiat Prot Dosim 1996;66:29-32.

[24] Kron T. Thermoluminescence dosimetry and its applications in medicine--Part 1: Physics, materials and equipment. Australas Phys Eng Sci Med 1994;17:175-99.

[25] Yukihara EG, McKeever SW. Optically stimulated luminescence (OSL) dosimetry in medicine. Phys Med Biol 2008;53:R351-79.

[26] The 2007 Recommendations of the International Commission on Radiological Protection. ICRP Publication 103. Ann ICRP 2007;37:1332.

[27] 1990 Recommendations of the International Commission on Radiological Protection. ICRP Publication 60. Ann ICRP 1991;21:1-201. [28] Jabeen A, Munir M, Khalil A, Masood M, Akhter P. Occupational exposure from external radiation used in medical practices in Pakistan by film badge dosimetry. Radiat Prot Dosim 2010;140:396-401.

[29] Nassef MH, Kinsara AA. Occupational radiation dose for medical workers at a University Hospital. JTUSCI 2017;11:1259-66.

[30] Gray, JE, Bailey ED, Ludlow J. Dental staff doses with handheld dental intraoral X-ray units. Health Phys 2012;2:137-42. 